\title{
DOUBLING FARMERS’ INCOME BY 2022
}

\author{
Dr. P.V Srikala \\ Assistant Professor, Department of Commerce \& Business Management, \\ Chaitanya Institute of Science \& Technology (Deemed to be University) Warangal, \\ Telangana, India.
}

\begin{abstract}
Indian agriculture is passing through difficult times due to two consecutive drought situations in several parts of the country, thereby resulting into wide spread distress among farmers. Past strategy for development of the agriculture sector in India has focused primarily on raising agricultural output and improving food security \& did not explicitly recognize the need to raise farmers' income and did not mention any direct measure to promote farmers welfare. The net result has been that farmers income remained low, which is evident from the incidence of poverty among farm households. Low level of absolute income as well as large and deteriorating disparity between income of a farmer and non-agricultural worker constitute an important reason for the farmers' suicides during 1995 to 2004, and is also forcing more and more cultivators, particularly younger age group, to leave farming. This can cause serious adverse effect on the future of agriculture in the country. To provide a solution for all these, in February 2016, Prime Minister Narendra Modi announced a scheme "Doubling farmers' income" by 2022 by spelling out 6 points strategy.
\end{abstract}

Keywords: Poverty; Income; Non agriculture workers.

Cite this Article: Dr. P.V Srikala, Doubling Farmers' Income by 2022, International Journal of Management (IJM), 11 (1), 2020, pp. 9-14.

$\mathrm{http}: / /$ iaeme.com/Home/issue/IJM?Volume=11\&Issue=1

\section{INTRODUCTION}

Historically, India has been an agrarian country. But it was only after we attained independence that the future of the sector brightened. One of the brightest spots in the history of Indian agriculture was between the 1950 and the late 1960s - the Green Revolution resulted in incremental increase in production of food grains, especially wheat and paddy. However, we must have taken that improvement for granted, and did not make enough efforts to help that growth sustain longer than it did. The crisis we see today was building for decades, and skipped our notice - farming has lost the joy and has become a source of income for those who cannot opt for any other means to earn. The rural areas are facing food and livelihood crisis, more specifically the shortage of fodder and drinking water. Government needs to proactively address the situation and make more long term farmers centric policies 
related to irrigation, farm diversification, farm profitability and community support programs so as to socially and economically empower farmers.

Past strategy for development of the agriculture sector in India has focused primarily on raising agricultural output and improving food security. The net result has been a 45 per cent increase in per person food production, which has made India not only food self-sufficient at aggregate level, but also a net food exporting country. The strategy did not explicitly recognise the need to raise farmers' income and did not mention any direct measure to promote farmers welfare. The net result has been that farmers income remained low, which is evident from the incidence of poverty among farm households.

Low level of absolute income as well as large and deteriorating disparity between income of a farmer and non-agricultural worker constitute an important reason for the emergence of agrarian distress in the country during 1990s, which turned quite serious in some years. The country also witnessed a sharp increase in the number of farmers suicides during 1995 to 2004 - losses from farming, shocks in farm income and low farm income are identified as the important factors for this. The low and highly fluctuating farm income is causing detrimental effect on the interest in farming and farm investments, and is also forcing more and more cultivators, particularly younger age group, to leave farming. This can cause serious adverse effect on the future of agriculture in the country.

In February 2016, Prime Minister Narendra Modi had said farmers' income would be doubled by 2022 to mark 75 years of India's independence \& gave a call to the nation of doubling farm income by spelling out 6 points strategy. The government constituted an interministerial committee on April, 2016 to examine issues relating to 'Doubling of Farmers' Income' and recommend strategies to achieve the same. The Committee has identified seven sources of income growth namely,

- Focus on irrigation with sufficient budget, with the aim of "Per Drop More Crop".

- Provision of quality seeds and nutrients based on soil health of each field.

- Heavy investments in Warehousing and Cold Chains to prevent post-harvest crop losses.

- Promotion of value addition through food processing.

- Creation of a National Farm Market, removing distortions and e-platform across 585 Stations.

- Introduction of a New Crop Insurance Scheme to mitigate risks at an affordable cost.

- Promotion of ancillary activities like poultry, beekeeping, and fisheries.

\section{VARIOUS SCHEMES AND PROGRAMS INITIATED BY THE GOVERNMENT TO ACHIEVE THE TARGET OF DOUBLING OF FARMERS' INCOME}

- Pradhan Mantri Krishi Sinchai Yojana,

- Pradhan Mantri Fasal Bima Yojana,

- Paramparagat Krishi Vikas Yojana,

- Soil Health Card,

- Neem-Coated Urea and e-NAM Schemes

\subsection{Pradhan Mantri Krishi Sinchayee Yojana (PMKSY), 2015}

Government of India is committed to accord high priority to water conservation and its management. To this effect Pradhan Mantri Krishi Sinchayee Yojana (PMKSY) has been formulated with the vision of extending the coverage of irrigation 'Har Khet ko pani' and improving water use efficiency 'More crop per drop' in a focused manner with end to end 
solution on source creation, distribution, management, field application and extension activities.

PMKSY has been formulated amalgamating ongoing schemes viz.

- Accelerated Irrigation Benefit Programme (AIBP) of the Ministry of Water Resources,

- River Development \& Ganga Rejuvenation (MoWR,RD\&GR),

- Integrated Watershed Management Programme (IWMP)

- Department of Land Resources (DoLR)

- On Farm Water Management (OFWM)

- Department of Agriculture and Cooperation (DAC).

PMKSY has been approved for implementation across the country with an outlay of Rs. 50,000 crore in five years. For 2015-16, an outlay of Rs.5300 crore has been made which includes Rs. 1800 crore for DAC; Rs. 1500 crore for DoLR; Rs. 2000 crore for MoWR(Rs. 1000 crore for AIBP; Rs. 1000 crores for PMKSY).

\subsection{Pradhan Mantri Fasal Bima Yojana (PMFBY), 2016}

With a view to provide better insurance coverage to crops for risk mitigation, a crop insurance scheme namely Pradhan Mantri Fasal Bima Yojana (PMFBY) was launched. This scheme provides insurance cover for all stages of the crop cycle. The PMFB replaces all the prevailing yield insurance schemes in India. The scheme has been launched with an impetus on crop sector. The scheme has extended coverage under localized risks, post-harvest losses etc. and aims at adoption of technology for the purpose of yield estimation. Through increased farmer awareness and low farmer premium rates the scheme aims at increasing the crop insurance penetration in India. The PMFBY will replace the existing two schemes National Agricultural Insurance Scheme as well as the Modified NAIS.

The scheme covers Kharif, Rabi, annual commercial as well as horticultural crops.

- There will be a uniform premium of only $2 \%$ to be paid by farmers for all Kharif crops

- All Rabi crops $1.5 \%$

- In case of annual commercial and horticultural crops, the premium to be paid by farmers will be only $5 \%$.

- The premium rates to be paid by farmers are very low and balance premium will be paid by the Government to provide full insured amount to the farmers against crop loss on account of natural calamities.

- There is no upper limit on Government subsidy. Even if balance premium is $90 \%$, it will be borne by the Government.

This scheme provides insurance cover for all stages of the crop cycle including postharvest risks in specified instances. Claims of Rs. 8,665 crore were paid to 553.01 lakh farmers in the year 2018-19.

\subsection{Paramparagat Krishi Vikas Yojana(PKVY), 2015}

PKVY Scheme aims at development of sustainable model of organic farming through a mix of traditional wisdom \& modern science to ensure long term soil fertility buildup, resource conservation $\&$ helps in climate change adaptation \& mitigation. This scheme primarily encourages the farmers to adopt eco-friendly concept of cultivation \& reduce their dependence on fertilizers.

PKVY aims at empowering farmers through institutional development through cluster approach not only in the farm practice management, input production, quality assurance but also in value addition \& direct marketing through innovative means. 
- Fifty or more farmers will form a cluster having 50 acre land to take up the organic farming under the scheme. In this way during three years 10,000 clusters will be formed covering 5.0 lakh acre areas under organic farming.

- There will be no liability on the farmers for expenditure on certification.

- Every farmer will be provided Rs. 20,000 per acre in three years for seed to harvesting of crops and to transport produce to the market.

- Organic farming will be promoted by using traditional resources and the organic products will be linked with the market.

- It will increase domestic production and certification of organic produce by involving farmers

\subsection{Soil Health Card Scheme, 2015}

Under this scheme, the government plans to issue soil cards to farmers which will carry cropwise recommendations of nutrients and fertilisers required for the individual farms to help farmers to improve productivity through judicious use of inputs. All soil samples are to be tested in various soil testing labs across the country. Thereafter the experts will analyse the strength and weaknesses (micro-nutrients deficiency) of the soil and suggest measures to deal with it. The result and suggestion will be displayed in the cards.

The government plans to issue the cards to 14 crore farmers.

An amount of 568 crore (US\$82 million) was allocated by the government for the scheme.

In 2016 Union Budget of India100 crore (US\$14 million) has been allocated to states for making soil health cards and set up labs.

As of July 2015, only 34 lakh Soil Health Cards (SHC) were issued to farmers as against a target of 84 lakh for the year 2015-16.

\subsection{Neem-Coated Urea and e-NAM Schemes, 2016}

The electronic market pilot across India was launched on 14 April 2016 is an online trading platform for agricultural commodities in India. The market facilitates farmers, traders and buyers with online trading in commodities. The market is helping in better price discovery and provides facilities for smooth marketing of their produce. The market transactions stood at 36,200 crores by January 2018, mostly intra-market. Over 90 commodities including staple food grains, vegetables and fruits are currently listed in its list of commodities available for trade. The eNAM markets are proving popular as the crops are weighed immediately and the stock is lifted on the same day and the payments are cleared online. In February 2018, some attractive features like MIS, dash board, BHIM and other mobile payments, enhanced features on the mobile app such as gate entry and payment through mobile phones and farmers database is helping adoption even more. The present trading is done mostly for intra-market, but in phases, it will be rolled out to trade in inter-market, inter-state, creating a unified national market for agricultural commodities.

National Agriculture Market Scheme Features:

- A National e-market platform for transparent sale transactions and price discovery in regulated markets, kisan mandis, warehouses and private markets. Willing States to accordingly enact provision for e-trading in their APMC Act.

- Liberal Licensing of traders / buyers and commission agents by State authorities without any pre-condition of physical presence or possession of shop / premises in the market yard.

- One license for a trader valid across all markets in the State.

- Harmonization of quality standards of agricultural produce and provisions of assaying (quality testing) infrastructure in every market to enable informed bidding by buyers. 
- Restriction of agriculture Produce Marketing Committee's (APMC) jurisdiction to within the APMC market yard / sub yard instead of a geographical area (the market area) at present.

- Single point levy of market fees i.e. on the first wholesale purchase from the farmer.

SFAC will implement the national e-platform and will cover 400 and 185 mandis during 2016-17 and 2017-18 respectively.

The government is planning to link 22,000 mandis across the country with the National Agriculture Market (e-NAM), an online trading platform for agricultural commodities by 2021-22, budgetary outlay of the Agriculture Ministry has been increased to Rs 2,11,694 crore during 2014-19, to develop and implement schemes to improve the farmers' situation in the country.

\section{OTHER MEASURES TO ACHIEVE DOUBLING FARMERS' INCOME SCHEME}

- 'Operation Greens' to address price volatility of perishable commodities like Tomato, Onion and Potato (TOP).

- PM Kisan Sampada Yojana to promote food processing in a holistic manner.

- Giving a major boost for the farmers' income, the Government has approved the increase in the Minimum Support Price (MSPs) for all Kharif \& Rabi crops for 2018-19 seasons at a level of at least 150 percent of the cost of production.

- With a view to provide income support to all farmers' families across the country, to enable them to take care of expenses related to agriculture and allied activities as well as domestic needs, the Central Government started a new Central Sector Scheme, namely, the Pradhan Mantri Kisan SAmman Nidhi (PM-KISAN). The scheme aims to provide a payment of Rs. 6000/- per year, in three 4-monthly installments of Rs. 2000/- to the farmers, subject to certain exclusions relating to higher income groups. An amount of Rs. 12646.579 crore has been distributed to 632.32895 lakh farmers in the year 2018-19.

- With a view to provide social security net for Small and Marginal Farmers (SMF) as they have minimal or no savings to provide for old age and to support them in the event of consequent loss of livelihood, the Government has decided to implement another new Central Sector Scheme for providing old age pension to these farmers. Under this Scheme, a minimum fixed pension of Rs. 3000/- be provided to the eligible small and marginal farmers, subject to certain exclusion clauses, on attaining the age of 60 years. The scheme aims to cover around 5 crore beneficiaries in the first three years. It would be a voluntary and contributory pension scheme, with entry age of 18 to 40 years. The Government has approved a budgetary provision of Rs. 10774.50 crore for the scheme till March, 2022.

\section{CONCLUSION}

The Rural Areas Are Facing Food And Livelihood Crisis, More Specifically The Shortage Of Fodder And Drinking Water. Government Needs To Proactively Address The Situation And Make More Long Term Farmers Centric Policies Related To Irrigation, Farm Diversification, Farm Profitability And Community Support Programs So As To Socially And Economically Empower Farmers.

To Provide A Solution For All These, In February 2016, Prime Minister Narendra Modi Announced A Scheme "Doubling Farmers' Income" By 2022 By Spelling Out 6 Points Strategy. 


\section{REFERENCES}

[1] Chand Ramesh, Addressing agrain distress: Sops Versus Development, $23^{\text {rd }}$ Dr. B.P Pal memorial lecture, May 26, Indian Agricultural Research Institute, New Delhi, 2016

[2] Chand Ramesh, Why doubling Farmers' Income by 2022 is Possible, Indian Express, Opinion page, April 15, 2016

[3] Chand Ramesh, e-plat form for National Agricultural Market, Economic \& Political Weekly, Vol. LI, No. 28, July 9, 2016

[4] Prathap B N, Dr Mahesh K and Karthik K R, Impact of Micro Finance on Poverty Alleviation, Journal of Management, 5(4), 2018,pp. 278-286

[5] Chand Ramesh \& Pavithra s, Fertilizers use \& Imbalance: Analysis of States, special article, Economic \& Political Weekly, Oct, Vol 50 no 44, 2015, pp. 139-145.

[6] "Raising Agricultural Productivity and Making Farming Remunerative for Farmers," Occasional Paper NITI Aayog, Government of India. (2015)

[7] Muhamad Toyib Daulay, Elfindri, Sjafrizal and Sofyardi, An Empirical Investigation of Business Diversification and Economic Value on Poverty in Batubara Regency, North Sumatera, Indonesia, International Journal of Civil Engineering and Technology, 9(10), 2018, pp. 841-859

[8] Chand, Ramesh, Saxena, R. and Rana, S, "Estimates and Analysis of Farm Income in India, 1983-84 to 2011-12," Economic \& Political Weekly, 50(22), 2015

[9] Chandrasekhar and Mehrotra, Doubling Farmerse Incomes by 2022: What Would It Take?" Economic \& Political Weekly, 51(18), 2016

[10] Dr. Johnson Nnadi Ewelum, Mbara Kingsley Ugochukwu, Community Services Training and Development: A Panacea for Employment Generation and Poverty Eradication in Families and Communities in Nigeria, International Journal of Management (IJM), 5(11), 2014, pp. 86-95

[11] Expert Committee, Report of the Expert Committee on Land Leasing, NITI Aayog, Government of India, 31 March. NSSO 2005: Income, Expenditure and Productive Assets of Farmer Households, Report No 497(59/33/5), National Sample Survey Office, Ministry of Statistics and Programme Implementation, Government of India, 2016

[12] Dr. N. Sundaram, Cherian Thomas and Dr. Ajay Kumar Sharma, Poverty condition of Artisanal Fishermen during Lean Season-a Review, International Journal of Mechanical Engineering and Technology, 9(7), 2018,pp. 728-735

[13] Ramesh Chand, 2017. Doubling farmers "e income. NITI Policy Paper 1/2017.

[14] C. T. Manjunatha, Dr. E.A. Parameswara Gupta, Role of Micro Finance in Poverty Alleviation, International Journal of Management (IJM), 5(3), 2014, pp. 73-77

[15] Recommendations of the National Round Table Conference on doubling the Farmers Income by 2022. 30 April, 2016. Indian Council of Food and Agriculture. 